\title{
Green Card
}

National Cancer Institute

\section{Source}

National Cancer Institute. Green Card. NCI Thesaurus. Code C19485.

A card issued by the U.S. Immigration Service verifying that the person has been granted status as a permanent resident of the United States and is eligible to receive a training or career award (Alien Registration Receipt Card I-55). 